scatter and throw each individual set of traits into identically sized groups balanced about the central value, we can calculate the correlation by the very simple formula,

$$
r=1\left[-\frac{\Sigma(X-Y)^{2}}{K},\right.
$$

where $X$ and $Y$ are the actual grade values given to the various items and $K$ is a constant equal to half the possible maximum value of $\Sigma(X-Y)^{2}$. The method of correlating persons had been used for some years without its essential difference from correlation of tests being clearly stated. It is to the credit of Stephenson that in his papers on "The Inverted Factor Technique" he has defined these differences and directed attention to the advantages of the method.

We have sampled the methods and results of experimental psychology and trust that the sample is a fair one, though possibly somewhat overloaded with ancient history that has become of interest to physicists in contact with the human factor. The sample is statistically inadequate, but has, we hope, enabled the mind to perform its accus. tomed trick of reaching conclusions from cues or data logically and mathematically altogether insufficient. We have seen psychologists using physical measurements and developing methods of dealing with the new forms of data so obtained. We have seen them following intuitive perception in the belief that their material had quantitative elements not at present amenable to the measurements of the physicist, replacing the scales of physics by estimates, ranking, grading and rating scales and developing mathematics to deal with these new data. We have seen them progressing step by step into more and more difficult fields of inquiry, and may look forward with confidence to yet greater achievements. In these circum. stances, does it matter much if some continue to believe, with Malebranche, Leibniz and Kant, that our data contain nothing "that can properly be called measurements" and that it is presumption for us to think that, in any reasonable sense, our data, theories, methods and results constitute "a systematic science"? After all, there is a sense in which logical and mathematical proofs are what the psychology of advertising has called "rationalization copy". Scientific insight, as everyday perception, has ever run ahead of measurement and mathematical proof.

\title{
OBITUARIES
}

\section{Prof. Edward Westermarck}

$\mathrm{E}^{\mathrm{n}}$ DWARD WESTERMARCK, whose death at the age of seventy-seven is reported from Finland, must always rank as one of the world's great anthropologists ; and, moreover, in view of the fact that his first and perhaps most famous work "The History of Human Marriage" appeared so early as 1891, only one year later than "The Golden Bough", he can be counted arnong the actual pioneers of anthropology in its social aspect. Born in 1862 at Helsingfors, he might be said to be connected since his birth with its University, his father being the bursar and his mother a daughter of the librarian; and here, having graduated and taken his doctorate with a thesis on primitive marriage, he became lecturer and afterwards professor of philosophy; only deserting his alma mater after the War of 1914-18, when he was appointed by a liberated Finland to organize as Rector a new Swedishspealing university at Abo.

Meanwhile, Helsingfors had always treated Westermarch with great liberality, providing him with travelling scholarships in five different years so that he might study, first in England, and later in Morocco ; and afterwards tolerating an arrangement whereby, when he had served as.professor in Finland during the winter months, ho could spend the summer term in London as lecturer at the School of Economics and afterwards as holder of a Martin White chair of sociology. Term over in London, he would slip off quietly to Morocco, where he was as much at home as at Box Hill ; and for his friends it amounted almost to a game of thimble-rig to guess at any moment where his elusive presence might be discovered.

Westermarck's first book, a masterpiece of detailed research, proved him not only to be exceedingly well informed-he had the reading-room of the British Museum to thank for that--but likewise to be a trained philosopher whose empirical leanings had led him to pay special attention to the theory of evolu. tion. Indced, he tells us in his autobiography ("Memories of my life", 1929) that already by 1887 he had decided to write about human marriage on lines suggested by Darwin's "Descent of Man", and with special reference to the problem "how to explain the veil of modesty and discretion that is thrown over the sexual life". Further, Alfred Russel Wallace helped him in the preparation of his argument with critical advice, and went on to furnish his book with an interesting preface in which he praises both its thoroughness and its philosophic quality. This subject, then, Westermarck made his own and his second and much enlarged edition in three volumes (1921), as well as the "Short History of Marriage" (1926), must always retain high authority.

A second magnum opus, "The Origin and Development of the Moral Ideas", is also a classic, even if 
it may suffer a little by comparison with its predecessor, which dealt with a more determinate theme. Perhaps, too, it was unfortunate that the first volume, concerned largely with philosophical generalities, was issued in 1906, and the second volume some two years later ; for the latter bore chief witness to the solidity of the inductive treatment on which the author relied. In "Early Beliefs and their Social Influence" (1932), various essays occur that throw further light on his views about ethics, as also about religion, towards which he adopted a frankly agnostic attitude.

His latest views on this subject are to be found in "Christianity and Morals" (1939), a considerable work full of interesting material.

It remains only to say something about Westermarck's studies of the social institutions of Morocco, which country from 1898 onwards ho had resolved to make his special field of first-hand investigation. Such works as "Marriage Ceremonies in Morocco" (1914), wherein he deals largely with the magical side of marriage ritual, a subject which his "History" had passed by, or "Ritual and Belief in Morocco" (1926), not to mention various minor writings, display his infinite capacity for collecting facts, conjoined with the analytic power that can reduce an apparently chaotic material to a lucid order. Indeed, Westermarck the ethnographer would bear a most distinguished namo were it not that Westermarck the ethnologist had to some extent eclipsed himself. Finland may well be proud of having produced such a man, to know whom was a liberal education.

R. R. MARETT.

\section{Prof. M. B. Krol}

7 HE death occurred on August 6 of Prof. Mikhail Borisovich Krol, the eminent neuro. pathologist and director of the clinic for nervous disorders of the All-Union Institute of Experimental Medicine and of the Second Moscow Medical Institute.

Prof. Krol was born in 1879 . He graduated from the medical faculty of the University of Moscow in 1901 and at first worked as assistant in the clinic for disorders of the higher nervous activities for women in Moseow under the direction of Prof. Minor, and in a number of clinics and laboratories in western Europe. In 1921 he took an active part in the foundation of the Belorussian University and of the medical faculty in Minsk. In 1924 he occupied the chair for nervous disorders in the Belorussian University, and was elected dean of the University. In 1931 he was elected a member of the Belorussian Academy of Sciences, and in 1939 became a membercorrespondent of the Academy of Sciences of the U.S.S.R.

In 1932, Prof. Krol was appointed director of the chair of nervous disorders in the Second Moscow Medical Institute and director of the clinic for nervous disorders of the Institute of Higher Norvous Activities, now the All-Union Institute of Experimental Medicino. During 1934-38 ho was chief physician of the Kremlin Hospital in Moscow. In 1935 he headed the Soviet delegation to the second International Neurological Congress in London. From June 1938, Prof. Krol directed the clinical section of the Institute of Experimental Medicine. He was the author of more than a hundred scientific works in Russian and other Ianguages, among which are several monographs of first importance. Ho was president of the Moscow and All-Union societies of neuropathologists and psychiatrists. He was vicepresident of the Medical Council of the Soviet Union, and editor of the journal Soviet Neuropathology and Psychiatry.

\section{NEWS AND VIEWS}

\section{A.R.P. for Animals}

The Royal Society for the Prevention of Cruelty to Animals has issued a very useful booklet on "Animals and Air Raids" containing the A.R.P. for animals drawn up by its veterinary experts, and the demand has been so great that a second edition was immediately required. In addition to tho usual veterinary treatments for burns, injuries, and gas contamination, described in $\approx$ manner convenient for animal-owners at a time when only a limited number of veterinary surgeons will be available, there are some well thought-out practical hints in these difficult problems. It is stated that there are in Greater London-approximately 40,000 horses, 9,000 cattle, 6,000 sheep, 18,000 pigs, 400,000 dogs, $1,500,000$ cats ; that there are some 200,000 working horses in England and Wales and in addition 1,004,686 agricultural horses. For horses on the streets, a halter and $12-\mathrm{ft}$. lead is advised to control the horse while unharnessing and then securing it at a spot away from falling masonry; the nosebag should be put on to keep it calm. For small dogs and domestic animals, a gas-proof air-tight box with an opening covered by a blanket dipped in a saturated solution of chloride of lime or permanganate of potash is recommended, and a similar device against gas is recommended for adapting stables, shippons and byres.

TrE Government anti-gas ointment No. 1 is among the treatments recommended for mustard gas contamination of animals, and anti-gas ointment No. 2 can be smeared on vulnerable parts of a horse, as the legs below the knee and hock joints, when it has to be led through streets that may still be contaminated. The former, a powerful irritant, is composed of equal parts of stabilized bleaching powder and vaseline, the latter of chloramine $T$ in a vanishing-cream base, but it is not stable. Both ointments are only for brief treatment. Petrol swabs or chloride of lime paste with frequent washes of 